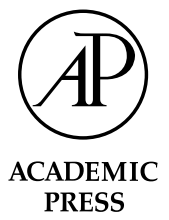

Available online at www.sciencedirect.com Science $\mathcal{O}^{\text {DiREct }}{ }^{\circledR}$

\title{
Letter to the Editor
}

\section{Comment on "A test of annual resolution in stalagmites using tree rings"}

Betancourt et al. (2002) present an interesting short paper where they review tree ring and stalagmite chronologies for the southern USA. We welcome this contribution, as it raises several important considerations about the use of stalagmites in obtaining high-resolution climate proxies. In particular, we welcome and agree with the assertion that the annual nature (or otherwise) of laminae in stalagmites needs to be confirmed for each individual sample. Additionally, we agree that each individual stalagmite contains a unique climate or environmental signal, which requires individual calibration of individual samples. Finally, we welcome the interdisciplinary approach of comparing contrasting proxies (tree rings and stalagmite lamina) to test and compare proxies. However, the short paper is somewhat empirical in nature, relying on statistical tests of two individual time series, and has a particular emphasis (by its nature) on individual proxies from New Mexico, USA. Because of this, we feel the paper paints an overly bleak situation of the use of laminae in speleothems, which we would like to address here using both theoretical and empirical evidence from a wide literature base.

\section{Subannual, annual, and supraannual laminae}

We recognize that laminae in speleothems can be subannual, annual, or supraannual. The nature of the laminae likely to be present can be understood with a basic knowledge of how both laminae form and how organic matter are transported from the surface to the cave. Laminae can be formed both as visible alternations of calcite structure (frequently from porous to compact calcite or calcite-aragonite pairs; Genty, 1993; Genty and Quinif, 1996; Genty et al., 1997; Qin et al., 1998) and from luminescent bands of organic matter (Baker et al., 1993). Laminae formed from variations in calcite texture rely on regular alternations of drip-water chemistry, which may alter the saturation state and therefore the carbonate precipitated, or they can also be formed by regular alternations of the cave atmosphere, such as changes in relative humidity or carbon dioxide concentration. Luminescent laminae rely on variations in luminescent organic matter fluxes from the surface (see, for example, drip-water calibration experiments in Baker et al., 1999b, 2000). In either case, subannual laminae may be preserved. Indeed, these have been reported in calibration experiments over the historical time period (see, for example, Baker et al., 1999a, ), where they have been demonstrated to occur due to both extreme rainfall events, generating a second organic matter flush per year, and extreme snowcover, generating a similar pulse. Indeed, Linge et al. (2001) demonstrate using both TIMS U-Th and lamina counting that a typical "year" in a stalagmite from Rana, Norway, comprises two laminae, one from spring snowmelt and one from autumn flushing of soil organic matter. Therefore it is important to recognize that the annual (or otherwise) nature of laminae will vary with climate: regions with strong seasonality of climate (such as within the Chinese monsoon region, see Ming et al., 1997) will preserve laminae with a frequency appropriate to the number of seasonal climate forcings. Second, it is important to understand something of the nature of karst hydrology. Stalagmites sampled from nearer the surface are more likely to have less mixing with storage water and a more rapid response to surface climate and are more likely to record individual climate events-such samples are likely to record subannual laminae. With increasing depth there will be a greater mixing of stored and event water, such that at deep cave sites stalagmites are unlikely to record any laminae, or maybe just those from supraannual extreme events. In between these two depths, there should be an optimum zone where stalagmites are most likely to record laminae that are annual in nature: this zone will of course vary with the geology.

\section{Verification of climate signals in annual laminae}

Betancourt et al. (2002) state that "as yet, there have been few efforts to crossdate or verify climate signals in 'annual' bands from speleothems." We feel it appropriate here to mention a few studies where such efforts have taken place. Baker et al. (1999a) compare annual and subannual laminae in two stalagmites from an English cave site deposited over the last 100 years with instrumental rainfall records. Proctor et al. (2000) compare annual laminae in a Scottish stalagmite with instrumental rainfall and temperature and North Atlantic Oscillation 
records for the last 120 years. Proctor et al. (2002) perform a similar analysis which also includes a comparison with historical sea surface temperature data. Ming et al. (1997) compare laminae in a Chinese stalagmite with instrumental rainfall and temperature data. Baker et al. (2002) investigate subannual laminae in a Scottish stalagmite for the last 1000 years in comparison with instrumental and historical data. Genty and Quinif (1996) demonstrate correlations between rainfall (water excess) and laminae thickness in several Recent Belgian stalagmites. Finally, drip-water monitoring experiments can also provide useful information on the links between surface climate and stalagmite deposition, for example, an interannual correlation between mean annual rainfall and drip rate (in the Père-Noël Cave, Belgium; Genty and Deflandre, 1998).

\section{Comparing stalagmite and tree ring proxies}

We agree wholeheartedly with Betancourt et al. (2002) that this approach should be encouraged. A first step is to understand both the strengths and weaknesses of both stalagmite and tree ring climate reconstructions, and we hope this paper goes some way toward the former. Indeed, one of the authors is promoting such an approach through the European Science Foundation HOLIVAR workshop on "Combining Climate Proxies," and technical papers on the advantages and disadvantages of all high-resolution Holocene climate proxies can be accessed at http://www.gsf.fi/ esf_holivar/. We welcome the publication of the comparison of tree-ring and stalagmite data for New Mexico by Betancourt et al.(2002), which is in a similar spirit, and would like to make only one comment on their list of possible explanations for a lack of agreement between the two proxies as stated in Betancourt et al. (2002, p. 199). This is the suggestion that the two proxies are responding to different climate forcing. We would like to suggest that it is quite likely, as the authors' point out, that the tree ring width is most strongly correlated with cool season precipitation. Stalagmite growth rate is most strongly correlated with drip water calcium concentration (see Baker et al 1998), which in turn is controlled by soil $\mathrm{CO}_{2}$ concentrations, which are driven by soil moisture and temperature. Second to this is a drip rate control on growth rate and therefore lamina width. Therefore, lamina width in Carlsbad is likely to be controlled by a complex combination of summer and winter precipitation and temperature, and not cool season precipitation. Indeed, careful climate calibration of the Carisbad stalagmite record could provide complimentary data to the tree ring evidence. We draw the readers' attention to Lutenbacher et al. (2002) who employed a similar approach of comparing historical, documentary, tree ring, ice core, and stalagmite proxies of winter North Atlantic Oscillation (wNAO): in this case a stalagmite record (Proctor et al.,
2000), which had a correlation of $r=0.64$ over the instrumental period against the wNAO, yielded a correlation of $r$ $=0.00$ against the longer instrumental/documentary based proxy, usefully demonstrating the problems of separating correlation and co-relation when using necessarily short instrumental data.

Finally, we would like to take the opportunity to correct Betancourt et al. (2002) in the suggestion that the stalagmite site in Assynt, NW Scotland, published by Proctor et al. (2000) is in a climate region with contemporaneous tree ring chronologies. Strong local climate gradients, the predominant calibration of stalagmite laminae width against precipitation rather than temperature, and the lack of local trees to the sample site since regional forest declines in the mid Holocene all prevent a useful comparison with regional tree ring chronologies.

\section{References}

Baker, A., Genty, D., Dreybrodt, W., Barnes, W.L., Mockler, N.J., Grapes, J., 1998. Testing theoretically predicted stalagmite growth rate with recent annually laminated samples: implications for past stalagmite deposition. Geochimica et Cosmochimica Acta 62, 393404

Baker, A., Genty, D., Fairchild, I.J., 2000. Hydrological characterisation of stalagmite dripwaters at Grotte de Villars, Dordogne, by the analysis of inorganic species and luminescent organic matter. Hydrology and Earth System Sciences 4, 439-449.

Baker, A., Mockler, N.J., Barnes, W.L., 1999b. Fluorescence intensity variations of speleothem forming groundwaters: implications for palaeoclimate reconstruction. Water Resources Research 35, 407413

Baker, A., Proctor, C.J., Barnes, W.L., 1999a. Variations in stalagmite luminescence laminae structure at Poole's Cavern, England, AD1910 to 1996: calibration of a palaeoprecipitation proxy. The Holocene 9, 683-688.

Baker, A., Proctor, C.J., Barnes, W.L., 2002. Stalagmite lamina doublets: a 1,000 year record of extreme winters in NW Scotland. International J. of Climatology 22, 1339-1345.

Baker, A., Smart, P.L., Edwards, R.L., Richards, D.A., 1993. Annual banding in a cave stalagmite. Nature $364,518-520$.

Betancourt, J.L., Grissiono-Mayer, H.D., Saltzer, M.W., Swetnam, T.W, 2002. A test of "annual resolution" in stalagmites using tree rings. Quaternary Research 58, 197-199.

Genty, D., 1993. Mise en évidence d'alternances saisonnières dans la structure interne des stalagmites. Intérêt pour la reconstitution des paléoenvironnements continentaux, Comptes Rendus de l'Academic des Sciences Paris Sén 2 317, 1229-1236.

Genty, D., Baker, A., Barnes, W.L, 1997. Comparison entre les lamines luminescentes et les lamines visibles annualles de stalagmites. Cómptes Rendus de l'Academie des Sciences 325, 193-200.

Genty, D., Baker, A., Vokal, B., 2001. Inter and intra annual growth rates of European stalagmites. Chemical Geology 176, 193-214.

Genty, D., Deflandre, G., 1998. Drip flow variations under a stalactite of the Père Noël Cave (Belgium). Evidence of seasonal variations and air pressure constraints. Journal of Hydrology 211, 208-232.

Genty, D., Quinif, Y, 1996. Annually laminated sequences in the internal structure of some Belgian stalagmites-importance for paleoclimatology. Journal of Sedimentary Research 66, 275-288. 
Linge, H.C., Lauritzen, S.E., Baker, A., Proctor, C.J., 2001. Luminescent growth banding and a stable isotope stratigraphy in a stalagmite from Northern Norway: preliminary results for the period AD1720 to 1000 $\mathrm{BC}$, in Proceedings, 13th International Congress of Speleology, Brasilia. [Abstract].

Lutenbacher, J., et al., 2002. Extending the North Atlantic Oscillation reconstructions back to 1500. Atmospheric Science Letters doi:10.1006/asle.2001.0044.

Ming, T., Xiaoguang, Q., Tungsheng, L., 1997. Microbanding of stalagmite and its significance. Journal of Chinese Geography 7 , $16-25$

Proctor, C.J., Baker, A., Barnes, W.L., 2002. A three thousand year record of north Atlantic climate. Climate Dynamics 19, 449-454.

Proctor, C.J., Baker, A., Barnes, W.L., Gilmour, M.A., 2000. A thousand year speleothem proxy record of North Atlantic climate from Scotland. Climate Dynamics 16, 815-820.

Qin, X., Liu, D., Tan, M., Li, T., Lu, J., Gu, Z., Lu, H., Ding, Z., Guo, Z., Liu, J., Nie, G, 1998. Grey characteristics of microbanding of stalagmite in Shihua Cave, Beijing and its climatic signification (I). Science in China (Series D) 41, 151-157.
Andy Baker ${ }^{\mathrm{a}, *}$

Dominique Genty ${ }^{\mathrm{b}}$

${ }^{a}$ Centre for Land Use and Water Resources Research University of Newcastle Newcastle NE1 7RU, UK

${ }^{\mathrm{b}}$ Laboratoire des Sciences du Climat et de l'Environnement LSCE UMR CEA/CNRS 1572 Bat 709

L'Orme des Merisiers

CEA Saclay

91191 Gif sur Yvette cedex, France

E-mail address: andy.baker@ncl.ac.uk

doi:10.1016/S0033-5894(03)00038-3

* Corresponding author. Fax: +44-191-222-5421. 